\title{
Development and implications of a revised Canadian Healthy Eating Index (HEIC-2009)
}

\author{
Sarah J Woodruff 1 ** and Rhona M Hanning ${ }^{2}$ \\ ${ }^{1}$ Department of Kinesiology, University of Windsor, 401 Sunset Avenue, Windsor, Ontario, N9B 3P4, Canada: \\ ${ }^{2}$ Department of Health Studies and Gerontology, University of Waterloo, Waterloo, Ontario, Canada
}

Submitted 12 March 2009: Accepted 30 November 2009: First published online 15 January 2010

\begin{abstract}
Objective: The purpose was to update the Healthy Eating Index-C (HEI-C) with Canada's new food guide recommendations (HEIC-2009) and compare scores and ratings among a small sample of grade 6 students.

Design: Updates to the HEI-C were completed with Canada's new food guide recommendations for daily number of servings. HEI-C and HEIC-2009 scores were computed for a small sample $(n 405)$ of grade 6 students utilizing nutrition data that were collected using the Food Behaviour Questionnaire, a validated web-based dietary assessment tool (including a $24 \mathrm{~h}$ dietary recall, FFQ, and food and physical activity behavioural questions).

Setting: Data were collected in fifteen schools in the Region of Waterloo District School Board, Ontario, Canada.

Subjects: A total of 405 students (48\% males and $52 \%$ females) from grade 6 classrooms completed the web-based survey.

Results: The index scores revealed that participants scored higher $(74 \cdot 5 v \cdot 69 \cdot 6$, $P<0 \cdot 001)$ using the HEIC-2009 compared with the HEI-C, even though both index scores are rated in the 'needs improvement' category (HEIC-2009, 75\%; HEI-C, $71 \%$ ). A small group of participants ( $n$ 14), who were previously rated (using the HEI-C) in the 'poor' category, were rated in the 'needs improvement' category using the HEIC-2009 $\left(\chi^{2}=589 \cdot 647\right.$, df $\left.=4, P<0 \cdot 001\right)$.

Conclusions: The HEIC-2009 has the potential to be used as a population-level diet quality index in Canada.
\end{abstract}

Keywords
Diet quality
Nutritional assessment
Over the past several decades, researchers have struggled with how to define healthy diets among the population. Several different types of methodologies, such as (i) factor and cluster analyses ${ }^{(1,2)}$, (ii) nutrient inadequacies ${ }^{(3)}$ and (iii) dietary quality indices ${ }^{(4-6)}$, have been proposed, including those which have also been associated with various health outcomes ${ }^{(7-9)}$. Factor and cluster analyses identify food consumption models or patterns in the data set (e.g. similar food intakes among a group of individuals) yet do not allow for comparisons against current dietary recommendations ${ }^{(10)}$. Measures of nutrient inadequacies compare an individual's nutrient intake with national recommendations, yet multiple days of food intake are needed to determine usual intake levels ${ }^{(11,12)}$. Finally, dietary quality indices evaluate the combination of different nutrients, foods or dietary constituents in relation to current dietary guidelines and/or specific health outcomes ${ }^{(10,13,14)}$. Numerous diet quality indices exist $^{(13)}$, yet must be chosen with a specific population and health outcome in mind to ensure the comprehensiveness and suitability of the index.
Within Canada, dietary quality indices have been used with adults ${ }^{(10,15)}$ and children and adolescents ${ }^{(14,16,17)}$. Dubois et $a l^{(10)}$ adapted three different measures of dietary quality with the 1990 Canadian nutrition recommendations, to analyse the Québec Nutrition Survey data (2103 males and females, aged 18-74 years). The authors adapted (i) the Dietary Quality Index (DQI) ${ }^{(18)}$, (ii) the Healthy Eating Index (HEI) ${ }^{(19)}$ and (iii) the Healthy Diet Indicator $(\mathrm{HDI})^{(20)}$. The results ${ }^{(10)}$ suggested that the HEI was the best indicator for their data set: correlations existed between the HEI and the mean adequacy ratio (MAR, which averages the proportion of dietary recommendations met by an individual for each nutrient; similar to what has been reported by Mirmiran et al. ${ }^{(21)}$ in children and adolescents). Furthermore, Dubois et al. ${ }^{(10)}$ concluded that because the HEI measure is a continuous measure (as opposed to discrete), it is easy to interpret and allows for a greater variety of statistical analyses.

Recently, Glanville and McIntyre ${ }^{(16)}$ adapted the HEI ${ }^{(19)}$ to reflect (then) Canada's Food Guide to Healthy Eating $(\mathrm{CFGHE})^{(22)}$ and used this to assess diet quality of 
low-income mothers ( $n$ 129) and children and adolescents ( $1-3$ years, $n$ 82; 4-8 years, $n$ 147; 9-14 years, $n 74$ ) from Atlantic Canada. The variety score and sodium category were changed from the original $\mathrm{HEI}^{(16)}$. The variety score was manipulated to a score based on consuming at least one serving from each food group, rather than the total number of different foods consumed. The sodium category was changed to the number of servings consumed from the other food group according to CFGHE (e.g. all foods that do not fit into the other four categories). Based on the Canadian modifications to the original HEI derived by the US Department of Agriculture (USDA), Glanville and McIntyre ${ }^{(16)}$ termed their measure the HEI-C (refer to Table 1 for how to calculate). Possible scores range from 0 to 100 , with 100 points referring to a perfect diet quality and any deviation(s) from the recommendations resulting in lower scores. Participants' diets can be categorized as 'poor' (HEI-C score $\leq 50$ ), 'needs improvement' (HEI-C score $=50-80)$ or 'good' (HEI-C score $>80)^{(16,19)}$.

In 2005, the USDA Center for Nutrition Policy and Promotion and the National Cancer Institute revised the original HEI (now being referred to as the HEI$2005)^{(23,24)}$. This update, in conjunction with the release of Eating Well with Canada's Food Guide (EWCFG) ${ }^{(25)}$, has prompted a revision of the HEI-C. The purpose of the current paper was, therefore, to update the HEI-C with Health Canada's new EWCFG recommendations (herein referred to as the HEIC-2009) for children and adolescents and to discuss potential limitations and future research directions.

\section{Methods}

\section{Participants}

A cross-sectional study design was used. Participants were recruited from the Region of Waterloo District School Board in Southern Ontario, Canada. Schools were selected to represent a cross-section of neighbourhoods in Waterloo Region based on a comparison of socioeconomic and demographic variables from the 2001 Statistics Canada Census and the 2001 Urban Poverty data. A total of 405 students ( $48 \%$ males and $52 \%$ females) from grade 6 classrooms in fifteen schools completed the webbased survey, representing a student response rate (i.e. students who were in class on the day of the survey with a returned parental consent form) of $57 \%$. All procedures were approved by the University of Waterloo's Office of Research Ethics.

\section{Procedure}

The validated web-based Food Behaviour Questionnaire $^{(26)}$ was used to assess nutrient intake and food behaviours through the use of a $24 \mathrm{~h}$ dietary recall and other nutrition behaviour questions. Details of the survey and procedures have been reported elsewhere ${ }^{(17,26,27)}$. Briefly, participants completed the questionnaire independently during class time (in the school's computer lab), which took approximately $30-40 \mathrm{~min}$. The $24 \mathrm{~h}$ recall collects data separately for breakfast, lunch, dinner and other times. Nutrient analysis software (The Food Processor version 7.9; Esha Research, Salem, OR, USA) processed the $24 \mathrm{~h}$ recall measures of food intake based on portion-size definitions of the 2001b Canadian Nutrient File database and according to (then) $\mathrm{CFGHE}^{(22)}$. Some participants ( $n$ 10) were excluded from further analysis due to implausible energy intakes $(<837 \mathrm{~kJ} / \mathrm{d}$ $(<200 \mathrm{kcal} / \mathrm{d})$ or $>25104 \mathrm{~kJ} / \mathrm{d}(>6000 \mathrm{kcal} / \mathrm{d}), n 4)$, and/ or unrealistic intakes based on visual inspection of any record with $>3$ times the upper servings recommendation from any food group ( $n 7)$, or both $(n 3)$.

\section{New scoring for the HEIC-2009}

Based on the new EWCFG ${ }^{(25)}$ recommendations, a new HEIC-2009 dietary quality index is proposed in which half of the scores ( 50 out of 100 points) have been revised. Table 1 compares the minimum and maximum scores of the HEI-C and the newly updated HEIC-2009 for those aged $9-13$ years. The primary changes are the grains and vegetables/fruit components, as $\mathrm{EWCFG}^{(25)}$ recommends 6 servings from grains (rather than 5-12 servings) and 6 servings of vegetables/fruit (rather than 5-10 servings) for 9- to 13-year-olds. Moreover, the recommendation is absolute, $v$. relative to energy, and therefore no longer scored taking into account total energy $(\mathrm{kJ} / \mathrm{d}, \mathrm{kcal} / \mathrm{d})$.

\section{Results}

The index scores revealed that participants scored higher $(74.5$ v. 69.6, $P<0 \cdot 001)$ using the HEIC-2009 compared with the HEI-C (see Table 2); even though both index scores are rated in the needs improvement category. Moreover, grain, vegetables/fruit and meat scores were all higher and milk scores were lower in the HEIC-2009 version compared with the HEI-C. Not surprisingly, this follows the same pattern as the $\mathrm{EWCFG}^{(25)}$ recommendations: the new guidelines generally have lower recommendations for grains (6 servings/d $v$. a range of 5-12), vegetables/fruit (6 servings/d $v$. a range of 5-10) and meat (now 1-2 servings/d v. 2-3) and higher for milk (now 3-4 servings/d $v$. 2-3). Finally, when the participants' scores were categorized into poor, needs improvement and good, the HEIC-2009 classified all participants in the same category, except a small group (14 of 29) of participants previously categorized in the poor category who were now categorized in the needs improvement category (see Table 3 ). The theoretical and measured differences (even among a small sample such as this) between the two indices (HEI-C and the newly updated HEIC-2009) have prompted some concerns 
Table 1 Minimum and maximum scores of the HEI-C v. HEIC-2009 for 9- to 13-year-old children and adolescents

\begin{tabular}{|c|c|c|c|c|c|}
\hline \multirow[b]{2}{*}{ Component } & \multicolumn{2}{|l|}{$\mathrm{HEI}-\mathrm{C}^{*}$} & \multicolumn{2}{|l|}{ HEIC-2009 } & \multirow[b]{2}{*}{ Considerations for subsequent $\mathrm{HEIC}$ calculations } \\
\hline & Maximum scores & Minimum scores & Maximum scores & Minimum scores & \\
\hline $\begin{array}{l}\text { Grains } \\
\quad(10 \text { points })\end{array}$ & $\begin{array}{l}\leq 6694 \mathrm{~kJ}(\leq 1600 \mathrm{kcal}): 5 \text { servings } \\
6694-9205 \mathrm{~kJ}(1600-2200 \mathrm{kcal}): \\
9 \text { servings } \\
\geq 9205 \mathrm{~kJ}(\geq 2200 \mathrm{kcal}): 12 \text { servings }\end{array}$ & 0 servings & $\geq 6$ servings & 0 servings & $\begin{array}{l}\text { Half of daily intake should be from whole grains } \\
\text { Grain products should be lower in fat, sugar } \\
\text { or salt }\end{array}$ \\
\hline $\begin{array}{l}\text { Vegetables/fruit } \\
\text { (20 points) }\end{array}$ & $\begin{array}{l}\leq 6694 \mathrm{~kJ}(\leq 1600 \mathrm{kcal}): 5 \text { servings } \\
6694-9205 \mathrm{~kJ}(1600-2200 \mathrm{kcal}): \\
7 \text { servings } \\
\geq 9205 \mathrm{~kJ}(\geq 2200 \mathrm{kcal}): 10 \text { servings }\end{array}$ & 0 servings & $\geq 6$ servings & 0 servings & $\begin{array}{l}\text { One dark green vegetable daily } \\
\text { One dark orange vegetable daily } \\
\text { Vegetables and fruit should be prepared with little } \\
\text { or no added fat, sugar or salt } \\
\text { Have vegetables and fruit more often than juice }\end{array}$ \\
\hline $\begin{array}{l}\text { Milk } \\
\text { (10 points) }\end{array}$ & $\begin{array}{l}\leq 6694 \mathrm{~kJ}(\leq 1600 \mathrm{kcal}): 2 \text { servings } \\
6694-9205 \mathrm{~kJ}(1600-2200 \mathrm{kcal}): \\
2 \text { servings } \\
\geq 9205 \mathrm{~kJ}(\geq 2200 \mathrm{kcal}): 3 \text { servings }\end{array}$ & 0 servings & $\begin{array}{l}\leq 6694 \mathrm{~kJ}(\leq 1600 \mathrm{kcal}): 3 \text { servings } \\
6694-9205 \mathrm{~kJ}(1600-2200 \mathrm{kcal}): \\
3.5 \text { servings } \\
\geq 9205 \mathrm{~kJ}(\geq 2200 \mathrm{kcal}): 4 \text { servings }\end{array}$ & 0 servings & $\begin{array}{l}\text { Drink skimmed, } 1 \% \text { or } 2 \% \text { milk daily } \\
\text { Select lower-fat milk alternatives }\end{array}$ \\
\hline $\begin{array}{l}\text { Meat } \\
\text { (10 points) }\end{array}$ & $\begin{array}{l}\leq 6694 \mathrm{~kJ}(\leq 1600 \mathrm{kcal}): 2 \text { servings } \\
6694-9205 \mathrm{~kJ}(1600-2200 \mathrm{kcal}): \\
2 \cdot 5 \text { servings } \\
\geq 9205 \mathrm{~kJ}(\geq 2200 \mathrm{kcal}): 3 \text { servings }\end{array}$ & 0 servings & $\begin{array}{l}\leq 6694 \mathrm{~kJ}(\leq 1600 \mathrm{kcal}): 1 \text { serving } \\
6694-9205 \mathrm{~kJ}(1600-2200 \mathrm{kcal}): \\
1.5 \text { servings } \\
\geq 9205 \mathrm{~kJ}(\geq 2200 \mathrm{kcal}): 2 \text { servings }\end{array}$ & 0 servings & $\begin{array}{l}\text { Have meat alternatives often } \\
\text { Eat at least two servings of fish each week } \\
\text { Select lean meat and alternatives prepared with } \\
\quad \text { little or no added fat or salt }\end{array}$ \\
\hline $\begin{array}{l}\text { Other } \\
\text { (10 points) } \dagger\end{array}$ & $\begin{array}{l}\leq 6694 \mathrm{~kJ}(\leq 1600 \mathrm{kcal}): \leq 4 \text { servings } \\
6694-9205 \mathrm{~kJ}(1600-2200 \mathrm{kcal}): \\
\quad \leq 6 \text { servings } \\
\geq 9205 \mathrm{~kJ}(\geq 2200 \mathrm{kcal}): \leq 8 \text { servings }\end{array}$ & $\begin{array}{l}\leq 6694 \mathrm{~kJ}(\leq 1600 \mathrm{kcal}): \\
>8 \text { servings } \\
6694-9205 \mathrm{~kJ} \\
(1600-2200 \mathrm{kcal}): \\
>11 \text { servings } \\
\geq 9205 \mathrm{~kJ}(\geq 2200 \mathrm{kcal}): \\
>14 \text { servings }\end{array}$ & $\begin{array}{l}\leq 6694 \mathrm{~kJ}(\leq 1600 \mathrm{kcal}): \leq 4 \text { servings } \\
6694-9205 \mathrm{~kJ}(1600-2200 \mathrm{kcal}): \\
\quad \leq 6 \text { servings } \\
\geq 9205 \mathrm{~kJ}(\geq 2200 \mathrm{kcal}): \leq 8 \text { servings }\end{array}$ & $\begin{array}{l}\leq 6694 \mathrm{~kJ}(\leq 1600 \mathrm{kcal}): \\
>8 \text { servings } \\
6694-9205 \mathrm{~kJ} \\
(1600-2200 \mathrm{kcal}): \\
>11 \text { servings } \\
\geq 9205 \mathrm{~kJ}(\geq 2200 \mathrm{kcal}): \\
>14 \text { serving }\end{array}$ & \\
\hline $\begin{array}{l}\text { Total fat } \\
\quad(10 \text { points })+\end{array}$ & $\leq 30 \%$ energy from fat & $\geq 45 \%$ of energy from fat & $\leq 30 \%$ of energy from fat & $\geq 45 \%$ of energy from fat & $\begin{array}{l}\text { Current Dietary Reference Intakes have changed } \\
\text { (e.g. } 20-35 \% \text { total fat is acceptable) } \\
\text { Include } 2-3 \text { tbsp of unsaturated fat each day }\end{array}$ \\
\hline $\begin{array}{l}\text { Saturated fat } \\
\text { (10 points) } \dagger\end{array}$ & $\leq 10 \%$ energy from saturated fat & $\begin{array}{l}\geq 15 \% \text { of energy from } \\
\text { saturated fat }\end{array}$ & $\leq 10 \%$ of energy from saturated fat & $\begin{array}{l}\geq 15 \% \text { of energy from } \\
\text { saturated fat }\end{array}$ & \\
\hline $\begin{array}{l}\text { Cholesterol } \\
\text { (10 points) }+\end{array}$ & $<300 \mathrm{mg}$ & $\geq 450 \mathrm{mg}$ & $<300 \mathrm{mg}$ & $\geq 450 \mathrm{mg}$ & \\
\hline $\begin{array}{l}\text { Variety } \\
\qquad(10 \text { points })+\end{array}$ & $\begin{array}{l}\text { At least one serving from each } \\
\text { food group }\end{array}$ & $\begin{array}{l}\text { Failure to eat a serving } \\
\text { from any food group }\end{array}$ & $\begin{array}{l}\text { At least one serving from each } \\
\text { food group }\end{array}$ & $\begin{array}{l}\text { Failure to eat a serving } \\
\text { from any food group }\end{array}$ & \\
\hline Total score & 100 & 0 & 100 & 0 & \\
\hline
\end{tabular}


about using the new HEIC-2009 as a measure of healthy eating among children and adolescents.

\section{Discussion}

Using a sole indicator of healthy eating, such as the HEI-C/ HEIC-2009, provides various advantages over other methodologies, particularly at the population level ${ }^{(10,13)}$. Besides using Canadian recommendations, the ease of using a single measurement of diet quality rather than numerous indicators individually (such as overall energy intake, servings of food groups from a food guide, or nutrient intakes in relation to current recommendations) provides various statistical advantages ${ }^{(10)}$. Individuals consume foods, generally in combination with others ${ }^{(13,14)}$, so that investigating the overall diet using a comprehensive approach may be more useful than simply comparing individual nutrients with a specific health outcome. By analysing the diet in this manner, we are likely not to overlook other aspects of the diet and/or allow a deviation in one component to affect all of the other components ${ }^{(10,13,14)}$. Potentially problematic, however, is the

Table 2 HEI-C v. HEIC-2009 scores of grade 6 participants ( $n$ 395) from the Region of Waterloo, Canada

\begin{tabular}{|c|c|c|c|c|}
\hline \multirow[b]{2}{*}{ Component } & \multicolumn{2}{|c|}{ HEI-C } & \multicolumn{2}{|c|}{ HEIC-2009 } \\
\hline & Mean & SD & Mean & SD \\
\hline Grains* $^{*}$ & $5 \cdot 69$ & $2 \cdot 8$ & $7 \cdot 51$ & $2 \cdot 8$ \\
\hline Vegetables/fruit* & $9 \cdot 59$ & $6 \cdot 4$ & $12 \cdot 09$ & $6 \cdot 5$ \\
\hline Milk* & $8 \cdot 70$ & $2 \cdot 8$ & $7 \cdot 80$ & $2 \cdot 8$ \\
\hline \multirow[t]{2}{*}{ Meat* } & $6 \cdot 73$ & $3 \cdot 7$ & $8 \cdot 06$ & $3 \cdot 3$ \\
\hline & \multicolumn{2}{|c|}{ Mean } & \multicolumn{2}{|c|}{ SD } \\
\hline Other & \multicolumn{2}{|c|}{$8 \cdot 28$} & \multicolumn{2}{|c|}{$2 \cdot 9$} \\
\hline Total fat & \multicolumn{2}{|c|}{$7 \cdot 34$} & \multicolumn{2}{|c|}{$3 \cdot 2$} \\
\hline Saturated fat & \multicolumn{2}{|c|}{$5 \cdot 71$} & \multicolumn{2}{|c|}{3.9} \\
\hline Cholesterol & \multicolumn{2}{|c|}{$8 \cdot 80$} & \multicolumn{2}{|c|}{$2 \cdot 9$} \\
\hline \multirow[t]{2}{*}{ Variety } & \multicolumn{2}{|c|}{$8 \cdot 83$} & \multicolumn{2}{|c|}{$1 \cdot 4$} \\
\hline & Mean & SD & Mean & $\mathrm{SD}$ \\
\hline Total score* & $69 \cdot 63$ & $13 \cdot 2$ & $74 \cdot 46$ & $13 \cdot 2$ \\
\hline
\end{tabular}

HEI-C, Canadian Healthy Eating Index; HEIC-2009, HEI-C adapted with Canada's new food guide recommendations (2009).

${ }^{*}$ Paired $t$ tests suggest that the HEI-C and HEIC-2009 are statistically different, $P<0.001$. associated weighting of each component. Calculated as it is, all components are weighted similarly (e.g. 10 points) with the exception of vegetables/fruit (20 points) and a combined 20 points for total fat and saturated fat. The components may (or may not) all have equal effects on healthy eating, and therefore future research should attempt to determine which components and/or combination of components, in combination with weighting factors, are the most useful to include in a healthy eating index.

A noted difference in the HEIC-2009 ( $v$. the HEI-C) is that it calculates all of the food serving scores (e.g. 50 points or $50 \%$ of the total score) based on a discrete recommended serving, rather than using a density approach (based on total energy consumed). EWCFG was developed using population-based nutrient modelling with the Estimated Average Requirement (EAR) and Adequate Intake (AI) as criteria for nutrient adequacy ${ }^{(28)}$. To ensure that nutrient requirements could be met without consuming excess energy, the modelling scenarios were based on the Estimated Energy Requirement (EER) for a sedentary physical activity ${ }^{(28)}$. Opposing, the density approach has the advantage, perhaps, of being dependent on an individual's energy intake, and does not discriminate between individuals who consume lower or higher amounts of energy. Without such an approach, those who consume high amounts of energy daily will have a better chance at achieving the recommendations simply because they are consuming more food, which may not necessarily mean they are consuming a healthier diet. For example, the energy levels do not take into account individuals with inappropriately low energy intakes due to meal skipping or dieting, or higher energy intakes due to overeating. Interesting to note is that the recently revised USDA HEI-2005 $5^{(23,24)}$ has adopted a density approach to score all of the individual components (total fruit, whole fruit, total vegetables, dark green and orange vegetables and legumes, total grains, whole grains, milk, milk and beans, oils, saturated fat, sodium, energy from solid fats, alcoholic beverages, added sugars) such that all scores are expressed per $4184 \mathrm{~kJ}$ ( $1000 \mathrm{kcal})$. Then again, using a density approach for all components may be problematic, because of the difficulties in obtaining a true energy intake level. Under-reporting is

Table 3 Comparison of HEI-C and HEIC-2009 rating classifications

\begin{tabular}{|c|c|c|c|c|c|c|c|}
\hline & & \multicolumn{6}{|c|}{ HEIC-2009* } \\
\hline & & \multicolumn{2}{|c|}{ Good } & \multicolumn{2}{|c|}{ Needs improvement } & \multicolumn{2}{|c|}{ Poor } \\
\hline & & $n$ & column $\%$ & $n$ & column $\%$ & $n$ & column $\%$ \\
\hline $\mathrm{HEl}-\mathrm{C}$ & $\begin{array}{l}\text { Good } \\
\text { Needs improvement } \\
\text { Poor }\end{array}$ & $\begin{array}{r}84 \\
0 \\
0\end{array}$ & $\begin{array}{r}100 \\
0 \\
0\end{array}$ & $\begin{array}{r}0 \\
282 \\
14\end{array}$ & $\begin{array}{r}0 \\
100 \\
48\end{array}$ & $\begin{array}{r}0 \\
0 \\
15\end{array}$ & $\begin{array}{r}0 \\
0 \\
52\end{array}$ \\
\hline
\end{tabular}

HEI-C, Canadian Healthy Eating Index; HEIC-2009, HEI-C adapted with Canada's new food guide recommendations (2009).

*Kendall's coefficient of concordance suggests good agreement $(\kappa=0.97, P<0.001)$. 
a known limitation associated with nutrient intake, especially among adolescents ${ }^{(27,29)}$, females ${ }^{(27,30)}$ and those classified as overweight or obese ${ }^{(27,31)}$. However, since a different approach was used to revise EWCFG ${ }^{(25)}$, a different strategy will be necessary to establish a scoring scheme.

Certain aspects or components of the HEI-C/HEIC-2009 may influence the overall score. The diet quality scores are based on: grains (10 points), vegetables/fruits (20 points), milk products (10 points), meat and alternatives (10 points), other foods (10 points), total fat (10 points), saturated fat (10 points), cholesterol (10 points) and variety (e.g. more than 1 serving from each food group for 10 points). The inclusion of total fat and saturated fat, for a combined total of 20 points (a fifth of the score), may be high and rather unnecessary, especially for growing children and adolescents. Further, dietary cholesterol is not a major health indictor in children and adolescents. It may have been better to include body weight status (albeit not an indicator of healthy eating, but known to be highly correlated with healthy eating), added sugar intake, fast food frequency, sugar-sweetened beverage consumption, snacking or meal skipping, in lieu of one of the fat and/or cholesterol categories, as these are known nutritional issues in children and adolescents.

It is important for researchers (and those wanting to work with a healthy eating index) to reach a consensus about what defines healthy eating, so that the necessary components can be included. If a revised index were fully based on the recently released $\mathrm{EWCFG}^{(25)}$, several new components should be included (see Table 1), some of which have been included in the recently revised HEI$2005^{(24,25)}$, such as: eating at least one dark green and one orange vegetable each day, eating vegetables and fruit more often than juice, choosing whole grains at least half of the time, drinking lower-fat milk (skimmed, 1\%, 2\%) each day, consuming meat alternatives such as beans, lentils and tofu more often, eating at least two servings of fish each week, consuming a small amount of unsaturated fat each day, satisfying thirst with water, and finally choosing foods lower in fat, sugar and salt. Perhaps these new messages should be incorporated in the healthy eating index. A challenge will be trying to quantify or account for the new messages, such as 'more often' and/ or 'each week', especially where data collection relies on the use of $24 \mathrm{~h}$ recalls.

Finally, limited validation research has been done with eating indices ${ }^{(32)}$, particularly with inter- and intraindividual variability of the component scores with multiple days of food records. Further, validation of a Canadian healthy eating index against biomarkers and anthropometric and clinical parameters of nutrition status should also be completed. While the HEIC-2009 provides various advantages in the meantime, future research that investigates these limitations needs to be completed.

\section{Acknowledgements}

The research was funded by the Region of Waterloo Public Health. None of the authors had a personal or financial conflict of interest. S.J.W. and R.M.H. were both key contributors to this research. S.J.W. led in the manuscript writing, but both authors participated in methodology design, data collection and data interpretation.

\section{References}

1. Farchi G, Mariotti S, Menotti A et al. (1989) Diet and 20-y mortality in two rural population groups of middle-aged men in Italy. Am J Clin Nutr 50, 1095-1103.

2. Hulshof KFAM, Wedel M, Lowik MRH et al. (1992) Clustering of dietary variables and other lifestyle factors. J Epidemiol Community Health 46, 417-424.

3. Madden JP \& Yoder MD (1972) Program evaluation: food stamps and commodity distribution in rural areas of central Pennsylvania. Penn Agric Exp Sta Bull 78, 1-119.

4. Clark M \& Wakefield LM (1975) Food choices of institutionalized versus independent-living elderly. $\mathrm{J} \mathrm{Am}$ Diet Assoc 66, 1667-1672.

5. Davenport M, Roderick P, Elliott L et al. (1995) Monitoring dietary change in populations and the need for specific food targets: lessons from the North West Thames Regional Health Survey. J Hum Nutr Diet 8, 119-128.

6. Murphy SP, Rose D, Hudes M et al. (1992) Demographic and economic factors associated with dietary quality for adults in the 1987-88 Nationwide Food Consumption survey. J Am Diet Assoc 92, 1352-1357.

7. Burke BS, Beal VA, Kirkwood SB et al. (1943) Nutrition studies during pregnancy. Am J Obstet Gynecol 46, $38-52$.

8. Gage TB \& O'Connor K (1994) Nutrition and the variation in level and age patterns of mortality. Hum Biol 66, 77-103.

9. Kushi LH, Lew RA, Stare FJ et al. (1985) Diet and 20-year mortality from coronary heart disease: the Ireland-Boston diet-heart study. $N$ Engl J Med 312, 811-818.

10. Dubois L, Girard M \& Bergeron N (2000) The choice of a diet quality indicator to evaluate the nutritional health of populations. Public Health Nutr 3, 357-365.

11. Garriguet D (2004) Overview of Canadians' Eating Habits. http://www.statcan.ca/english/research/82-620-MIE/82-620MIE2006002.pdf (accessed July 2006).

12. Nusser SM, Carriquiry AL \& Dodd KW (1996) A semiparametric transformation approach to estimating usual daily intake distributions. J Am Stat Assoc 91, 1440-1449.

13. Kant AK (1996) Indexes of overall diet quality: a review. J Am Diet Assoc 96, 785-791.

14. Veugelers PJ, Fitzgerald AL \& Johnston E (2005) Dietary intake and risk factors for poor diet quality among children in Nova Scotia. Can J Public Health 96, 212-216.

15. Shatenstein B, Nadon S, Godin C et al. (2005) Diet quality of Montreal-area adults needs improvement: estimates from a self-administered food frequency questionnaire furnishing a dietary indicator score. J Am Diet Assoc 105, 1251-1260.

16. Glanville NT \& McIntyre L (2006) Diet quality of Atlantic families headed by single mothers. Can J Diet Pract Res 67, $28-35$.

17. Woodruff SJ, Hanning RM, Lambraki I et al. (2008) Healthy Eating Index-C is compromised among adolescents with body weight concerns, weight loss dieting, and meal skipping. Body Image 5, 404-408. 
18. Patterson RE, Haines PS \& Popkin BM (1994) Diet quality index: capturing a multidimensional behavior. $J$ Am Diet Assoc 94, 57-64.

19. Kennedy ET, Ohls J, Carlson S et al. (1995) The Healthy Eating Index: design and applications. J Am Diet Assoc 95, 1103-1108.

20. Huijbregts PPCW, Fesken E \& Rasanen L (1997) Dietary pattern and 20 year mortality in elderly men in Finland, Italy, and the Netherlands: longitudinal cohort study. BMJ 315, 13-17.

21. Mirmiran P, Azadbakht L \& Azizi F (2005) Dietary qualityadherence to the dietary guidelines in Tehranian adolescents: Tehran Lipid and Glucose Study. Int J Vitam Nutr Res 75, 195-200.

22. Minister of Public Works and Government Services Canada (1997) Canada's Food Guide to Healthy Eating for People Four Years and Over. Cat. No. H39-252/1992E. http:// www.hc-sc.gc.ca/fn-an/food-guide-aliment/index_e.html (accessed April 2006).

23. Guenther PM, Reedy J, Krebs-Smith SM et al. (2007) Development and Evaluation of the Healthy Eating Index2005: Technical Report. http://www.cnpp.usda.gov/ HealthyEatingIndex.htm (accessed January 2009).

24. Guenther PM, Reedy J \& Krebs-Smith SM (2008) Development of the Health Eating Index-2005. J Am Diet Assoc 108, 1896-1901.

25. Minister of Health Canada (2007) Eating Well with Canada's Food Guide. Cat. No. H164-38/1-2007E. http://www.hc-sc. gc.ca/fn-an/food-guide-aliment/index-eng.php (accessed July 2008)

26. Hanning RM, Royall D, Toews JE et al. (2009) Validation of the web-based Food Behaviour Questionnaire with grade six to eight Ontario students. Can J Diet Pract Res 70, $172-178$

27. Vance VA, Woodruff SJ, McCargar LJ et al. (2009) Selfreported dietary energy intake of normal weight, overweight, and obese adolescents. Public Health Nutr 12, 222-227.

28. Health Canada (2007) Eating Well with Canada's Food Guide. The Evidence Base. http://www.hc-sc.gc.ca/fn-an/foodguide-aliment/context/evid-fond/evidence-fondementseng.php (accessed February 2009).

29. Bandini LG, Schoeller DA, Cyr HN et al. (1990) Validity of reported energy intake in obese and nonobese adolescents. Am J Clin Nutr 52, 421-425.

30. Johansson L, Solvoll K, Bjorneboe GE et al. (1998) Underand overreporting of energy intake related to weight status and lifestyle in a nationwide sample. Am J Clin Nutr 68, 266-274.

31. Briefel RR, Sempos CT, McDowell MA et al. (1997) Dietary methods research in the third National Health and Nutrition Examination Survey: underreporting of energy intake. $\mathrm{Am} \mathrm{J}$ Clin Nutr 65, 4 Suppl., 1203S-1209S.

32. Guenther PM, Reedy J, Krebs-Smith SM et al. (2008) Evaluation of the Health Eating Index-2005. J Am Diet Assoc 108, 1854-1864. 